\title{
TINGKAT PRESTISE DAN PERSEPSI SISWA PADA CITRA SEKOLAH DAN PENGARUHNYA TERHADAP MOTIVASI BELAJAR SISWA
}

\author{
Rima Dhamayanti \\ SMK Sritanjung Banyuwangi \\ rimadhamayanti@gmail.com
}

\begin{abstract}
The research aims to examine the effect of prestige and students perception of school image on students' learning motivation. The sampling technique in this research is purposive random sampling. Students of SMK Ardjuna 1 Malang was choosen to be research sample. Data was collected by questionnaire and analyzed by multiple regression. Based on data analysis it can be concluded that there is no significant effect of student prestise on learning motivation, and there is a significant effect of students perception of school image on learning motivation.
\end{abstract}

Keywords: prestige, perception, school image, learning motivation

\begin{abstract}
Abstrak: Penelitian ini bertujuan untuk menguji pengaruh tingkat prestise dan persepsi siswa pada citra sekolah terhadap motivasi belajar siswa.Teknik pengambilan sampel pada penelitian ini adalah purposive random sampling. Populasi dalam penelitian ini adalah siswa jurusan akuntansi SMK Ardjuna 1 Malang yang berjumlah 130 siswa, dengan sampel sebesar 40 responden. Pengumpulan data menggunakan angket dan teknik analisis data menggunakan analisis regresi ganda. Berdasarkan analisis data diperoleh bahwa tidak terdapat pengaruh yang signifikan tingkat prestise siswa terhadap motivasi belajar siswa. Selain itu juga dapat diketahui bahwa terdapat pengaruh yang signifikan persepsi siswa pada citra sekolah terhadap motivasi belajar siswa.
\end{abstract}

Kata kunci: Prestise, Persepsi, Citra sekolah, Motivasi belajar

Motivasi merupakan faktor pendorong yang harus dimiliki oleh siswa dalam belajar, karena peserta didik akan belajar dengan sungguh-sungguh bila memiliki motivasi belajar yang tinggi. Begitu pula sebaliknya, apabila motivasi belajar yang dimiliki siswa rendah, maka proses pembelajaran akan terhambat dan tidak akan dapat mencapai tujuan belajar yang diharapkan. Hal tersebut sejalan dengan pendapat Sardiman (2005:84) yang menyatakan "hasil belajar atau prestasi belajar 
akan menjadi optimal kalau ada motivasi. Makin tepat motivasi yang diberikan, akan berhasil pula pelajaran itu". Jika didefinisikan, motivasi belajar adalah "keseluruhan daya penggerak psikis di dalam diri siswa yang menimbulkan kegiatan belajar, menjamin kelangsungan kegiatan belajar, dan memberikan arah pada kegiatan belajar itu demi mencapai suatu tujuan" (Winkel, 2005:169). Motivasi belajar memegang peranan penting dalam memberikan gairah atau semangat belajar, sehingga siswa yang memiliki motivasi kuat mempunyai energi untuk melakukan kegiatan belajar.

Motivasi yang ada pada seseorang dapat dibedakan menjadi dua macam, yaitu motivasi intrinsik dan motivasi ekstrinsik. Motivasi intrinsik adalah hal atau keadaan yang berasal dari dalam diri siswa sendiri yang dapat mendorongnya melakukan tindakan belajar. Motivasi tersebut timbul tanpa ada paksaan dorongan orang lain, tetapi atas dasar kemauan sendiri. Sedangkan motivasi ekstrinsik adalah hal atau keadaan yang datang dari luar individu siswa yang juga mendorong siswa untuk melakukan kegiatan belajar. Pengaruh ini dapat berupa ajakan, suruhan, atau paksaan dari orang lain sehingga dalam keadaan demikian siswa mau melakukan sesuatu atau belajar.

Dalam perspektif kognitif, motivasi yang lebih signifikan bagi siswa adalah motivasi intrinsik karena lebih murni dan langgeng serta tidak bergantung pada dorongan pengaruh orang lain. Dorongan mencapai prestasi dan dorongan memiliki pengetahuan dan keterampilan untuk masa depan, misalnya, memberi pengaruh lebih kuat dan relatif lebih langgeng dibandingkan dengan dorongan hadiah atau dorongan keharusan dari orang tua dan guru.

Menurut Branden (2005:7), kunci yang terpenting bagi motivasi manusia adalah "penghargaan atas diri". Pentingnya rasa penghargaan atas diri yang dimaksud di sini merupakan suatu rasa yang terkait dengan wibawa atau perbawa yang berkenaan dengan prestasi atau kemampuan. Rasa penghargaan atas diri ini adalah rasa bangga terhadap apa yang dimiliki. Siswa yang memiliki rasa bangga baik terhadap pribadinya maupun sekolahnya, maka senantiasa akan akan mampu menghargai prestasi, kemampuan, maupun potensi yang dicapai, sehingga ia memiliki motivasi untuk melakukan sesuatu demi mencapai tujuan yang diinginkan. 
Rasa bangga, prestise atau rasa penghargaan atas diri adalah keyakinan dan kemampuan untuk bertindak dan menghadapi tantangan dalam hidup (Branden,2005:3). Selain itu, dapat diartikan juga sebagai keyakinan untuk bahagia, layak, merasa berharga, dan memungkinkan untuk menegaskan kebutuhan-kebutuhan dan keinginan-keinginan serta menikmati buah dari hasil kerja keras.

Setiap manusia tidak dapat berharap untuk merealisasikan potensinya tanpa penghargaan atas diri yang sehat. Begitu pula dengan siswa, setiap prestasi yang berhasil diraih baik oleh dirinya sendiri maupun oleh sekolahnya pasti ingin dihargai secara layak sehingga mampu meningkatkan harga diri, wibawa, dan kehormatan. Hal ini tidak menutup kemungkinan bisa juga menimbulkan dorongan untuk menggali potensi yang dimiliki oleh setiap orang sehingga mencapai suatu prestasi atau hasil yang memuaskan seperti apa yang diinginkan. Begitu pula dengan siswa di sekolah. Siswa akan dapat mencapai penghargaan atas pribadi dan sekolahnya apabila ia mampu menghasilkan suatu prestasi atau kemampuan yang membuat harga diri atau wibawanya terangkat. Dengan kata lain, motivasi belajar siswa akan bertambah atas rasa penghargaan diri yang sehat atau prestise yang memang diikuti dengan potensi yang dimiliki.

Selain rasa bangga atau prestise pada sekolah, terdapat faktor intrinsik lain yang diduga berkontribusi terhadap motivasi belajar siswa yaitu persepsi siswa terhadap citra sekolah. Menurut McLaughlin (2006), citra sekolah yang terbentuk dipengaruhi oleh banyak faktor mulai dari kepemimpinan kepala sekolah yang profesional, guru-guru yang tangguh dan profesional, tujuan pencapaian filosofis yang jelas, lingkungan yang kondusif untuk pembelajaran, jaringan organisasi yang baik, kurikulum yang jelas, evaluasi belajar yang baik berdasarkan acuan patokan untuk mengetahui apakah tujuan pembelajaran dari kurikulum sudah tercapai, serta partisipasi orang tua murid yang aktif dalam kegiatan sekolah. Faktor-faktor inilah yang nantinya akan membentuk citra sekolah. Apabila sekolah tersebut memenuhi faktor-faktor tersebut di atas, maka sekolah tersebut dapat dikatakan sekolah unggulan sehingga persepsi siswa tentang citra sekolahnya akan baik atau positif. Demikian pula apabila sekolah belum memenuhi faktor yang mempengaruhi terbentuknya citra sebuah sekolah, maka 
sekolah tersebut belum dapat dikatakan sebagai sekolah unggulan sehingga persepsi siswa bersifat negatif tentang citra sekolahnya.

Berdasarkan latar belakang di atas dapat diduga ada pengaruh positif antara tingkat prestise dan persepsi siswa pada citra sekolahnya terhadap motivasi belajar. Secara teoritis, penelitian ini bermanfaat untuk menguji dan melihat keberlakuan teori motivasi menurut pandangan para ahli behaviouristik yang mengemukakan bahwa motivasi seseorang baru akan muncul jika ada rangsangan dari luar. Dalam hal ini motivasi yang dimaksud adalah motivasi belajar siswa. Sedangkan salah satu bentuk rangsangan dari luarnya adalah rangsangan yang berasal dari citra sekolahnya. Penelitian ini juga untuk menguji dan melihat keberlakuan teori persepsi yang menyatakan bahwa persepsi seseorang terhadap stimulus yang datang dapat mempengaruhi tingkah lakunya. Stimulus yang dimaksud di sini adalah citra sekolah yang menghendaki adanya respon dari siswa berupa motivasi untuk belajar. Selain itu, penelitian ini juga menguji teori mengenai prestise atau penghargaan atas diri yang sangat mempengaruhi motivasi manusia. Prestise siswa akan dipengaruhi oleh citra sekolah yang dimiliki siswa yang meliputi harga, prestasi atau kemampuan sekolah yang bersangkutan.Dalam hal ini tingkat prestise siswa sangat menentukan motivasi belajar yang dimiliki.

\section{METODE}

Penelitian ini adalah termasuk jenis penelitian eksplanasi (explanatory research). Penelitian eksplanasi adalah untuk menguji pengaruh antar variabel yang dihipotesiskan (Faisal, 2005:21). Penelitian ini berusaha untuk mengetahui pengaruh antara dua variabel bebas (independent variable), yaitu tingkat prestise siswa $\left(\mathrm{X}_{1}\right)$ dan persepsi siswa pada citra sekolah $\left(\mathrm{X}_{2}\right)$ terhadap satu variabel terikat, yaitu motivasi belajar siswa (Y).

Tingkat prestise siswa pada citra sekolah adalah tingkat kebanggaan atas prestasi atau kemampuan yang dimiliki oleh sekolah. Variabel ini diukur menggunakan skala sikap yang terdiri dari lima skala yang diadopsi dari model Likert's scale berupa skala penilaian 1-5. Indikator dari variabel ini meliputi perlakuan lingkungan keluarga, penilaian diri sendiri, keefektifan diri, self respect (rasa harga diri), dan perlakuan lingkungan masyarakat. Persepsi siswa pada citra 
sekolah adalah penilaian siswa terhadap faktor-faktor yang menentukan kelas atau tingkatan sekolah untuk dikategorikan sebagai sekolah unggulan. Seperti halnya pada variabel tingkat prestise siswa pada citra sekolah, variabel ini diukur menggunakan skala sikap yang terdiri dari lima skala yang diadopsi dari model likert's scale berupa skala penilaian 1-5. Variabel persepsi siswa pada citra sekolah dibagi menjadi beberapa sub variabel yaitu kepemimpinan kepala sekolah, kinerja profesionalitas guru, tujuan filosofis, lingkungan pembelajaran, jaringan organisasi, kejelasan kurikulum, evaluasi belajar, dan partisipasi orang tua murid. Motivasi belajar adalah suatu dorongan yang terjadi pada siswa untuk belajar. Variabel ini diukur menggunakan skala sikap yang terdiri dari lima skala yang diadopsi dari model likert's scale berupa skala penilaian 1-5. Variabel motivasi belajar dibagi menjadi dua subvariabel yaitu motivasi intrinsik dan ekstrinsik.

Populasi dalam penelitian ini adalah semua siswa jurusan akuntansi di SMK Ardjuna 1 Malang yang berjumlah 130 siswa. Sampel yang dipilih adalah sejumlah 40 sampel yang diambil secara acak dari siswa kelas tiga. Dengan demikian, pengambilan sampel dalam penelitian ini menggunakan teknik "purposive random sampling". Pertimbangan yang digunakan dalam memilih sampel dari siswa kelas tiga adalah karena siswa kelas tiga dianggap memiliki pengetahuan dan pengalaman lebih banyak dalam melakukan penilaian terhadap citra sekolahnya sehingga persepsi yang dimiliki diharapkan lebih objektif.

Jenis data pada penelitian ini terdiri dari data primer. Data primer yang dimaksud adalah data yang diperoleh dari subyek penelitian secara langsung, dalam hal ini data mengenai tingkat prestise siswa, persepsi siswa, dan motivasi belajar siswa. Mengacu pada jenis data yang hendak dikumpulkan dalam penelitian ini, maka teknik pengumpulan data yang dipergunakan adalah teknik angket. "Angket adalah sejumlah pertanyaan tertulis yang digunakan untuk memperoleh informasi dari responden dalam arti laporan tentang pribadi atau halhal yang diketahuinya" (Arikunto, 2006:151). Dasar pertimbangan penggunaan angket untuk pengumpulan data adalah karena faktor efisiensi dan efektitivitas dalam penggunaannya. Jenis angket ada dua macam yaitu angket terbuka dan angket tertutup. Penelitian ini menggunakan angket tertutup yaitu angket yang 
sudah menyediakan jawaban pertanyaan sehingga responden tinggal memilih saja.

Berdasarkan teknik pengumpulan data yang dipergunakan, maka instrumen (alat) pengumpulan datanya adalah angket (kuesioner). Arikunto (2002:128) mengemukakan "kuesioner adalah sejumlah pertanyaan tertulis yang digunakan untuk memperoleh informasi dari responden dalam arti laporan tentang pribadinya atau hal-hal lain yang diketahuinya". Dalam penelitian ini, angket (kuesioner) merupakan kumpulan pernyataan yang diajukan kepada responden secara tertulis, dan responden memberikan jawabannya dengan memberikan tanda cek $(\sqrt{ })$ pada alternatif kategori jawaban yang dianggap sesuai dalam kolom yang tersedia pada angket. Dalam upaya memperoleh keakuratan data yang dikumpulkan maka telah dilakukan uji coba instrumen memastikan valid dan reliabelnya instrumen tersebut.

Sehubungan dengan teknik analisis data, dalam penelitian ini teknik analisis yang dipilih adalah analisis regresi berganda. Arikunto (2002:286) menyatakan "analisis regresi berganda adalah analisis tentang pengaruh antara dua/lebih independent variable dengan satu dependent variable”.

\section{HASIL}

Berikut ini merupakan distribusi frekuensi untuk variabel tingkat prestise siswa kelas 3 AK A SMK Arjuna 1 Malang.

Tabel 1. Distribusi Frekuensi Tingkat Prestise Siswa

\begin{tabular}{|c|c|c|c|c|}
\hline No. & Interval & Klasifikasi & Frekuensi & Presentase \\
\hline 1. & $41-50$ & Sangat tinggi & - & \\
\hline 2. & $32-40$ & Tinggi & 13 & $39,4 \%$ \\
\hline 3. & $23-31$ & Cukup & 15 & $45,5 \%$ \\
\hline 4. & $14-22$ & Rendah & 4 & $12,1 \%$ \\
\hline 5. & $5-13$ & Sangat Rendah & 1 & $3 \%$ \\
\hline \multicolumn{3}{|c|}{ Jumlah } & 33 & $100 \%$ \\
\hline
\end{tabular}

Berdasarkan tabel di atas diketahui bahwa dari 33 siswa yang diteliti, ada 13 siswa yang memiliki tingkat prestise tinggi atau dengan presentase 39,4\%. Siswa yang memiliki tingkat prestise cukup tinggi sebanyak 15 siswa atau sebesar 45,5\%. Sedangkan siswa yang memiliki tingkat prestise rendah sebanyak 4 siswa atau sebesar $12,1 \%$. Sedangkan siswa yang memiliki tingkat prestise yang sangat rendah sebanyak 1 siswa atau sebesar $3 \%$. 
Tabel 2 berikut ini merupakan distribusi frekuensi untuk variabel tingkat prestise siswa kelas 3 AK A SMK Arjuna 1 Malang.

Tabel 2. Distribusi Frekuensi Persepsi Siswa pada Citra Sekolah

\begin{tabular}{|l|l|l|l|l|}
\hline No. & Interval & Klasifikasi & Frekuensi & Presentase \\
\hline 1. & $92-109$ & Sangat Baik & - & \\
\hline 2. & $76-91$ & Baik & 13 & $39,4 \%$ \\
\hline 3. & $58-75$ & Cukup & 15 & $45,5 \%$ \\
\hline 4. & $40-57$ & Kurang Baik & 5 & $15,1 \%$ \\
\hline 5. & $22-39$ & Sangat Kurang Baik & & \\
\hline \multicolumn{2}{r}{ Jumlah } & 33 & $100 \%$ \\
\hline
\end{tabular}

Berdasarkan tabel di atas diketahui bahwa dari 33 siswa yang diteliti, ada 13 siswa yang memiliki persepsi pada citra sekolah yang baik atau dengan presentase $39,4 \%$. Siswa yang memiliki persepsi pada citra sekolah yang cukup baik sebanyak 15 siswa atau sebesar 45,5\%. Sedangkan siswa yang memiliki persepsi pada citra sekolah yang kurang baik sebanyak 5 siswa atau sebesar 15,1\%.

Tabel 3 berikut ini merupakan distribusi frekuensi untuk variabel motivasi belajar siswa kelas 3 AK A SMK Arjuna 1 Malang.

Tabel 3. Distribusi Motivasi Belajar Siswa

\begin{tabular}{|c|c|c|c|c|}
\hline $\mathrm{NO}$ & Interval & Klasifikasi & Frekuensi & Presentase \\
\hline 1. & $84-99$ & Sangat tinggi & - & - \\
\hline 2. & $68-83$ & Tinggi & 10 & $30,3 \%$ \\
\hline 3. & $52-67$ & Cukup & 15 & $45,5 \%$ \\
\hline 4. & $36-51$ & Rendah & 8 & $24,2 \%$ \\
\hline 5. & $20-35$ & Sangat Rendah & - & - \\
\hline \multicolumn{3}{|c|}{ Jumlah } & 33 & $100 \%$ \\
\hline
\end{tabular}

Berdasarkan tabel di atas diketahui bahwa dari 33 siswa yang diteliti, ada 10 siswa yang memiliki tingkat motivasi belajar yang tinggi atau dengan presentase $30,3 \%$. Siswa yang memiliki tingkat motivasi belajar yang cukup tinggi sebanyak 15 siswa atau sebesar $45,5 \%$. Sedangkan siswa yang memiliki tingkat motivasi belajar yang rendah sebanyak 8 siswa atau sebesar $24,2 \%$.

Analisis regresi berganda dilakukan untuk membuktikan hipotesis yang diujikan dalam penelitian, yaitu untuk mengetahui pengaruh dari dua variabel bebas terhadap satu variabel terikat baik secara parsial maupun simultan. Secara ringkas hasil uji regresi berganda disajikan pada tabel 4. 
Tabel 4. Ringkasan Hasil Uji Regresi Linier Berganda

\begin{tabular}{|l|l|l|l|l|l|}
\hline Varibel Bebas & Variabel terikat & B & Beta & T & $\begin{array}{l}\text { Sig } \\
(\mathrm{p})\end{array}$ \\
\hline Tingkat Prestise (X1) & Motivasi Belajar & 0.273 & 0.101 & 0.523 & 0.604 \\
\cline { 1 - 4 } $\begin{array}{l}\text { Persepsei siswa pada citra sekolah } \\
(\mathrm{X} 2)\end{array}$ & $\begin{array}{l}\text { Siswa (Y) } \\
\text { Constant }\end{array}$ & 0.550 & 0.499 & 2.572 & 0.014 \\
\hline Adj R square & 0.296 & & \\
\hline F & 9.214 & & \\
\hline Sig F & 0.001 & & \\
\hline
\end{tabular}

Dari uji $\mathrm{F}$ yang tingkat signifikansi perhitungannya sampai dengan 0,001 dan adjusted $R$ square sebesar 0,296 atau 29,6\%, dapat disimpulkan bahwa tingkat prestise siswa dan persepsi siswa pada citra sekolah secara bersama-sama mampu mempengaruhi motivasi belajar siswa sebesar 29,6\%. Setelah dilakukan uji t ternyata variabel tingkat prestise tidak signifikan secara statistik pada $\alpha=5 \%$. Sedangkan untuk variabel persepsi siswa pada citra sekolah dikatakan signifikan secara statistik pada $\alpha=5 \%$ sehingga dapat disimpulkan koefisien secara individual signifikan secara statistik.

Berdasarkan hasil penelitian seperti yang disajikan di atas, maka dapat ditentukan persamaan regresi sebagai berikut:

$$
\mathrm{Y}=14,263+0,273 \mathrm{X}_{1}+0,55 \mathrm{X}_{2}
$$

Dari persamaan regresi di atas, diketahui bahwa motivasi belajar siswa (Y) dapat diprediksikan oleh tingkat prestise $\left(\mathrm{X}_{1}\right)$ dan persepsi siswa pada citra sekolah $\left(\mathrm{X}_{2}\right)$. Bila tingkat prestise naik satu satuan berdasarkan pengukuran yang dibuat dalam penelitian ini, maka motivasi belajar siswa akan naik sebesar 0,273. Bila persepsi siswa pada citra sekolah naik satu satuan berdasarkan pengukuran yang dibuat dalam penelitian maka motivasi belajar siswa akan naik sebesar 0,55. selanjutnya akan diuraikan masing-masing pengujian hipotesis dalam penelitian ini.

Hipotesis pertama yang diajukan dalam penelitian ini berbunyi "Ada pengaruh yang signifikan dari tingkat prestise pada citra sekolah terhadap motivasi belajar siswa jurusan akuntansi di SMK Ardjuna 1 Malang". Sehubungan dengan hipotesis tersebut, selanjutnya dengan memperhatikan tabel 4 di atas, terlihat nilai t sebesar 0,523 dengan disertai oleh signifikansi t sebesar 0,604 atau $60,4 \%$, maka dapat disimpulkan bahwa tingkat prestise $\left(\mathrm{X}_{1}\right)$ tidak berpengaruh 
signifikan terhadap motivasi belajar siswa (Y), oleh karena signifikansi (probabilitas) yang menyertainya lebih besar dari 0,05 (0,604>0,05). Dengan kata lain signifikansi sebesar 0,604 ini merupakan nilai yang lebih besar dari 0,05 sebagaimana menjadi kriteria penerimaan dan penolakan hipotesis. Perolehan nilai tersebut dapat memberikan bukti bahwa tingkat prestise tidak berpengaruh terhadap motivasi belajar siswa jurusan akuntansi di SMK Ardjuna 1 Malang. Sehubungan dengan hal tersebut maka dapat disimpulkan bahwa hipotesis pertama yang diajukan dalam penelitian ini ditolak.

Hipotesis kedua yang diajukan dalam penelitian ini berbunyi "Ada pengaruh yang signifikan dari persepsi siswa pada citra sekolah terhadap motivasi belajar siswa jurusan akuntansi di SMK Ardjuna 1 Malang”. Sehubungan dengan hipotesis tersebut, selanjutnya memperhatikan tabel 4 di atas, terlihat nilai $\mathrm{t}$ sebesar 2,572 dengan disertai oleh signifikansi t sebesar 0,014 atau 1,4\%, maka dapat disimpulkan bahwa persepsi siswa pada citra sekolah $\left(\mathrm{X}_{2}\right)$ berpengaruh positif signifikan terhadap motivasi belajar siswa (Y), oleh karena signifikansi (probabilitas) yang menyertainya lebih kecil dari $0,05(0,014<0,05)$. Dengan kata lain signifikasi sebesar 0,014 ini merupakan nilai yang lebih kecil dari 0,05 sebagaimana menjadi kriteria penerimaan dan penolakan hipotesis. Perolehan nilai tersebut dapat memberikan bukti persepsi siswa pada citra sekolah berpengaruh terhadap motivasi belajar siswa jurusan akuntansi di SMK Ardjuna 1 Malang. Semakin meningkat persepsi siswa pada citra sekolahnya, maka akan semakin tinggi motivasi belajar siswa jurusan akuntansi di SMK Ardjuna 1 Malang. Sehubungan dengan hal tersebut maka dapat disimpulkan bahwa hipotesis kedua yang diajukan dalam penelitian ini diterima.

Hipotesis ketiga yang diajukan dalam penelitian ini berbunyi "Ada pengaruh yang signifikan dari tingkat prestise dan persepsi siswa pada citra sekolah terhadap motivasi belajar siswa jurusan akuntansi di SMK Ardjuna 1 Malang”. Sehubungan dengan hipotesis tersebut, tabel di atas menyajikan ringkasan hasil analisis regresi berganda yang menunjukkan nilai $F=9,214$ dengan signifikansi=0,001 atau $0,1 \%$. Berpijak pada perolehan nilai $F=9,214$ dengan signifikansi $=0,001$ atau $0,1 \%$ ini, maka dapat disimpulkan bahwa secara simultan (bersama-sama) tingkat prestise siswa $\left(\mathrm{X}_{1}\right)$ dan persepsi siswa pada citra 
sekolah $\left(\mathrm{X}_{2}\right)$ berpengaruh secara signifikan terhadap motivasi belajar siswa $(\mathrm{Y})$, oleh karena signifikansi (probabilitas) yang menyertainya lebih kecil dari 0,05 $(0,001<0,05)$.

Atas dasar hasil analisis regresi ganda sebagaimana dimaksud di atas, maka dapat disimpulkan bahwa semakin turun tingkat prestise siswa $\left(\mathrm{X}_{1}\right)$ dan semakin tingginya persepsi siswa pada citra sekolah $\left(\mathrm{X}_{2}\right)$ yang secara simultan (bersamasama) akan selalu diikuti oleh semakin tingginya motivasi belajar siswa jurusan akuntansi di SMK Ardjuna 1 Malang. Oleh karena pengaruh secara simultan yang terjadi pada tingkat prestise $\left(\mathrm{X}_{1}\right)$ dan persepsi siswa pada citra sekolah $\left(\mathrm{X}_{2}\right)$ terhadap motivasi belajar siswa jurusan akuntansi di SMK Ardjuna 1 Malang signifikan, dengan demikian maka hipotesis ketiga yang diajukan dalam penelitian ini diterima.

Berdasarkan hasil analisis data tabel 4 dapat pula nilai Adjusted $R$ square sebesar 0,296 atau 29,6\% merupakan kontribusi dari tingkat prestise $\left(\mathrm{X}_{1}\right)$ dan persepsi siswa pada citra sekolah $\left(\mathrm{X}_{2}\right)$ terhadap motivasi belajar siswa $(\mathrm{Y})$. Artinya perubahan motivasi belajar siswa yang ditimbulkan oleh tingkat prestise dan persepsi siswa pada citra sekolah secara simultan sebesar 29,6\%. Sedangkan sisanya sebesar $100 \%-29,6 \%=70,4 \%$ ini merupakan nilai besarnva kemungkinan berubahnya motivasi belajar siswa jurusan akuntansi $d$ Ardjuna 1 Malang yang disebabkan oleh variabel lain yang tidak termasul model analisis ini.

\section{PEMBAHASAN}

\section{Pengaruh Tingkat Prestise terhadap Motivasi Belajar Siswa}

Berkaitan dengan ditolaknya hipotesis pertama yang diujikan dalam penelitian sebagaimana berbunyi "tidak ada pengaruh yang signifikan antara tingkat prestise pada citra sekolah terhadap motivasi belajar siswa jurusan akuntansi di SMK Ardjuna 1 Malang", hal ini menunjukkan bahwa tingkat prestise tidak memiliki kontribusi terhadap motivasi belajar siswa jurusan akuntansi di SMK Ardjuna 01 Malang.

Pengaruh tingkat prestise yang tidak signifikan terhadap motivasi belajar siswa di SMK Ardjuna 1 Malang ini disebabkan oleh citra sekolah yang tidak 
dapat dikatakan sebagai sekolah unggulan. Sehingga dapat dikatakan bahwa tingkat prestise siswa terhadap sekolah rendah. Hal ini menyebabkan motivasi belajar siswa menjadi kurang. Oleh karena itu,tingkat prestise yang dimiliki siswa menjadi tidak signifikan secara parsial terhadap motivasi beajar siswa SMK Ardjuna 1 Malang.

\section{Pengaruh Persepsi Siswa pada Citra Sekolah terhadap Motivasi Belajar}

Berkaitan dengan diterimanya hipotesis kedua yang diujikan dalam penelitian sebagaimana berbunyi "ada pengaruh yang signifikan antara persepsi siswa pada citra sekolah terhadap motivasi belajar siswa jurusan akuntansi di SMK Ardjuna 1 Malang”, hal tersebut menunjukkan bahwa persepsi siswa pada citra sekolah memiliki kontribusi terhadap motivasi belajar siswa jurusan akuntansi di SMK Ardjuna 1 Malang.

Terbuktinya penerimaan hipotesis kedua ini dikarenakan persepsi siswa pada citra sekolah mempunyai pengaruh yang berarti dengan motivasi belajar dan hal itu sejalan dengan teori yang dikemukakan bahwa "interprestasi seseorang tentang kesan sensorinya mengenai lingkungannya akan sangat berpengaruh pada perilakunya yang pada gilirannya menentukan faktor-faktor apa yang dipandangnya sebagai faktor motivasional yang kuat" (Siagian, 1995).

\section{Pengaruh Tingkat Prestise dan Persepsi Siswa pada Citra Sekolah terhadap}

\section{Motivasi Belajar}

Berkaitan dengan diterimanya hipotesis ketiga yang diujikan dalam penelitian sebagaimana berbunyi "ada pengaruh yang signifikan antara tingkat prestise dan persepsi siswa pada citra sekolah terhadap motivasi belajar siswa jurusan akuntansi di SMK Ardjuna 1 Malang”, hal ini menunjukkan bahwa tingkat prestise dan persepsi siswa pada citra sekolah memiliki kontribusi terhadap motivasi belajar siswa jurusan akuntansi di SMK Ardjuna 1 Malang.

Terbuktinya penerimaan hipotesis ketiga ini dikarenakan tingkat prestise dan persepsi siswa pada citra sekolah mempunyai pengaruh yang berarti dengan motivasi belajar dan hal itu sejalan dengan teori yang dikemukakan oleh para ahli behaviouristik, motivasi dikontrol oleh kondisi lingkungan. Karena motivasi 
dikontrol oleh kondisi lingkungan, maka pembentukan citra sekolah dilakukan dengan maksimal sehingga agar siswa termotivasi untuk belajar. Suatu tingkah laku yang bermotivasi terjadi apabila konsekuensi dari tingkah laku itu dapat menjadikan emosi seseorang menjadi suka atau tidak suka. Apabila konsekuensi tingkah laku ini menimbulkan rasa suka, maka tingkah laku menjadi semakin kuat dan sebaliknya. Selain itu, hasil penelitian ini juga sesuai dengan pendapat umum bahwa faktor eksternal berupa lingkungan (citra sekolah) mempengaruhi motivasi belajar siswa secara bersama-sama.

\section{SIMPULAN}

Dengan memperhatikan hasil analisis maka dapat ditarik beberapa kesimpulan hasil penelitian sebagai berikut. Pertama, tingkat prestise yang diukur melalui angket tidak terbukti berpengaruh secara signifikan terhadap motivasi belajar siswa jurusan akuntansi di SMK Ardjuna 1 Malang. Hal tersebut dikarenakan tingkat prestise siswa terhadap citra sekolah tergolong rendah sehingga tidak signifikan secara parsial terhadap motivasi belajar siswa. Oleh karena itu, hasil penelitian ini kurang sejalan dengan teori bahwa tingkat prestise mempengaruhi motivasi belajar siswa. Kedua, persepsi siswa pada citra sekolah berpengaruh secara positif signifikan terhadap motivasi belajar siswa. Hal itu sesuai dengan teori yang menyatakan bahwa semakin baik persepsi siswa pada lingkungannya (citra sekolah) akan berdampak pada meningkatnya motivasi belajar siswa. Ketiga, tingkat prestise dan persepsi siswa pada citra sekolah bepengaruh secara simultan berpengaruh signifikan terhadap motivasi belajar. Hal itu sejalan dengan teori yang dikemukakan bahwa faktor eksternal berupa citra sekolah akan mempengaruhi motivasi belajar siswa.

Dengan memperhatikan hasil temuan dalam penelitian ini, maka dapat dikemukakan saran-saran dengan harapan agar memiliki manfaat yang berarti bagi banyak pihak. Pertama, pihak sekolah hendaknya mampu meningkatkan nilai atau citra sekolahnya menjadi sekolah yang lebih unggul, sehingga persepsi siswa pada citra sekolah akan menjadi lebih baik. Hal ini nantinya juga akan berpengaruh pada motivasi belajar siswa mengingat persepsi siswa memiliki pengaruh yang signifikan terhadap motivasi belajar siswa. Peneliti juga menyarankan kepada para 
pembaca yang berminat meneliti kasus yang sejenis, sebaiknya menggunakan penelitian sampel dengan wilayah sampel yang lebih besar. Penelitian diharap dilakukan pada beberapa sekolah sehingga hasil penelitian dapat menjadi lebih handal.

\section{DAFTAR RUJUKAN}

Arikunto, Suharsimi. 2006. Prosedur Penelitian: Suatu Pendekatan Praktik. Jakarta: PT Rineka Cipta.

Branden, Nathaniel. 2005. Kekuatan Harga Diri. Batam: Interaksara.

Faisal, Sanapiah. 2005. Format-format Penelitian Sosial. Jakarta: Raja Grafindo Grafika.

McLaughlin. 2006. Effective Schools Research and The Role of Professional Communities.

(Online), (http://www.fcoe.k12.ca.us/eduscrvc/spec_ed_docs\%5CEffective\%20Schoo 1s\%2010-04.ppt) http://teknologipendidikan.wordpress.com/2006/09/12/sekolah-unggulan/

Sardiman, A. 2005. Interaksi dan Motivasi Belajar Mengajar. Jakarta: PT Raja Grafindo Persada.

Winkel,WS. 2005. Psikologi Pengajaran. Jogjakarta: Media Abadi. 